\title{
Myoblast Transfer of Human Erythropoietin Gene in a Mouse Model of Renal Failure
}

\author{
Yasuo Hamamori, * Babru Samal, ${ }^{\ddagger}$ Jin Tian, ${ }^{\S}$ and Larry Kedes ${ }^{*}$ \\ *Institute for Genetic Medicine and Department of Biochemistry \& Molecular Biology, and ${ }^{\S}$ Division of Nephrology, Department of \\ Medicine, University of Southern California School of Medicine, Los Angeles, California 90033; ${ }^{\ddagger}$ Amgen Inc. Thousand Oaks, \\ California 91320-1789
}

\begin{abstract}
Anemia is an invariable consequence of end-stage renal failure (ESRF) and recombinant erythropoietin has dramatically improved the quality of life of patients with ESRF. As an alternative approach, we developed a myoblast gene transfer system for the systemic delivery of human erythropoietin (EPO). We recently reported that transplantation of $4 \times 10^{7}$ cells of a $\mathrm{C} 2$ myoblast cell clone that stably secretes high level of functional human EPO, increased hematocrit from $44.6 \pm 3.0$ to $71.2 \pm 7.9(\%)$ in $2 \mathrm{wk}$, and the increase was sustained for at least 12 wk in nude mice. $A$ renal failure model was created by a two-step nephrectomy in nude mice, and myoblasts were transplanted 3 wk after the second nephrectomy, when mean blood urea nitrogen level had increased from $26.3 \pm 6.1$ to $85.4 \pm 24.0(\mathrm{mg} /$ dl) and the hematocrit had decreased from $45.2 \pm 2.7$ to $33.9 \pm 3.7(\%)$. After transplantation, the hematocrit markedly increased to $68.6 \pm 4.2(\%) 2 \mathrm{wk}$, and to $68.5 \pm 4.0(\%)$ 7 wk after the transplantation. Serum human EPO concentration determined by ELISA indicated a persistent steady EPO production from the transplanted muscle cells 8 wk after the transplantation. The fate of transplanted myoblasts in uremic mice was monitored by transplanting the EPOsecreting clone which had also been transduced with BAG retrovirus bearing the $\beta$-galactosidase gene. 8 wk later, $X$ gal positive myofibers were detected in the entire transplanted area. The results demonstrate that myoblasts can be transplanted in uremic mice, and that myoblast gene transfer can achieve sufficient and sustained delivery of functionally active EPO to correct anemia associated with renal failure in mice. (J. Clin. Invest. 1995. 95:1808-1813.)
\end{abstract}

This work was presented in part at a Keystone Symposium on Gene Therapy, on January 17, 1994.

Address correspondence to L. Kedes, Institute for Genetic Medicine, HMR 413, USC School of Medicine, 2011 Zonal Ave., Los Angeles, CA 90033. Phone: 213-342-1144; FAX: 213-342-2764; e-mail: kedes@zygote.hsc.usc.edu.

Received for publication 22 September 1994 and in revised form 28 November 1994.

1. Abbreviations used in this paper: BUN, blood urea nitrogen; ELISA, enzyme linked immunosorbent assay; EPO, erythropoietin; ESRF, endstage renal failure; RIA, radioimmunoassay; X-gal, 5-bromo-4-chloro3-indolyl- $\beta$ D-galactoside.

J. Clin. Invest.

(C) The American Society for Clinical Investigation, Inc.

0021-9738/95/04/1808/06\$2.00

Volume 95, April 1995, 1808-1813
Key words: gene therapy $\bullet$ anemia $\cdot$ renal failure $\cdot$ muscle cell transplantation $\bullet$ nude mouse

\section{Introduction}

Anemia is an invariable consequence of end-stage renal failure. The use of recombinant human erythropoietin (EPO) ${ }^{1}$ has dramatically improved the quality of life of patients with endstage renal failure (1). However, this therapy requires frequent hospital visits by patients, limiting patients' life styles as well as job opportunities. As an alternate therapy, we attempted to establish a gene therapy protocol to systemically deliver this cytokine. The prime requirements of gene transfer approaches for systemic delivery of cytokines in general are: (1) sufficient and (2) sustained production of (3) the functional transgene product to achieve (4) a therapeutically significant systemic response. A successful gene therapy protocol should thus decrease frequent hospital visits for recombinant EPO therapy.

Gene therapy protocols for malignant tumors such as melanoma (2) and brain tumors (3) by local delivery of target genes have produced some therapeutic success in clinical trials. Although a number of gene therapy approaches have been tested for systemic delivery of cytokines $(4,5)$, gene therapy for systemic delivery of hormones and cytokines such as factor IX for the treatment of hemophilia, has not attained sustained normalization of the disease condition (for instance, normalization of bleeding time) in animal models. We have evaluated a myoblast gene transfer system to deliver human EPO. Myoblasts appear to be a highly suitable model for cell-mediated gene delivery. Myoblasts can be isolated from mammalian muscle tissue and manipulated easily in vitro, can be expanded through 20-50 doublings and made available in a large numbers $(6,7)$. The cells can be transduced or transfected with recombinant genes, and can be injected back into muscles for autologous or heterologous transplantation $(8-10)$. The unique biology of muscle cells allows the transplanted myoblasts to terminally differentiate and become part of myofibers by fusing to each other or fusing into preexisting myofibers; the transplanted nuclei and preexisting host nuclei are both sustained and active in this fused multinucleated myofibers which now serve as a stable source of transgene expression for lengthy periods (1013). Despite these many attributes of myoblast gene transfer, there has been no demonstration of long term normalization of any disease model by the method, and thus, the therapeutic feasibility of this approach for the systemic delivery of cytokines has yet to be established.

We have recently created $\mathrm{C} 2$ muscle cell clones that produce approximately 0.18 to $32.8 \mathrm{U} / \mathrm{ml}$ per $10^{6}$ cells per day of human EPO (14). The EPO produced from these muscle cell clones was functionally active as determined by an in vitro bioassay using an EPO-dependent cell line. Transplantation of the highest 
EPO-producing clone engendered persistent erythropoiesis in both $\mathrm{C} 3 \mathrm{H}$ mice, which are syngeneic with $\mathrm{C} 2$ cells, and nude mice (14). In the nude mice transplanted with this clone, a marked hematocrit increase lasted for at least 3 mon, while mice transplanted with parental C2 cells did not show a significant hematocrit change during the period.

The current major indication for recombinant human EPO administration is anemia associated with end-stage renal failure (15). Here, we demonstrate the efficacy of a myoblast gene therapy approach using an animal model of renal failure in nude mice. We have tested whether myoblasts can be transplanted and then secrete functional human EPO in an amount sufficient to correct anemia for a long term in these uremic mice. Transplantation of EPO-producing C2 cells generated marked erythropoiesis as efficiently as in non-uremic mice, suggesting that a myoblast gene transfer approach can be applied in renal failure mice as effectively as in normal mice. Thus, myoblast gene transfer may be feasible to correct anemia associated with renal failure as well as other types of EPO-responsive anemia.

\section{Methods}

Materials and animals. 7-8 wk-old male nude mice were used for all the experiments and purchased from Charles River Labs (Wilmington, MA). BUN kit (Sigma 535-A) was from Sigma Chemical Co. (St. Louis, MO). An ELISA system (Quantikine IVD) for EPO concentration measurement was from R \& D systems (Minneapolis, MN). The animal standard chow (Harlan Tekland ;8656) was from Harlan Tekland (Madison, WI).

Transfection and screening of clones. Human EPO-secreting C2 myoblast clones were described previously (14). These clones carry the 1.34-kb human EPO cDNA (starting at +190 nucleotide from the major transcription initiation site to the end of poly A tail) (16-18) cloned into the plasmid pRC/CMV (Invitrogen, San Diego, CA). This plasmid bears the cytomegalovirus enhancer/promoter $(19,20)$ to drive the EPO gene, and a neomycin resistance gene (21). The highest EPOproducing clone, hereafter called C2-EPO9, produces $\sim 33 \mathrm{U} / 10^{6}$ cells per day of human EPO as determined by radioimmunoassay. The functional activity of EPO produced by this clone was confirmed by an in vitro bioassay (14).

Myoblast transplantation. Myoblasts from C2-EPO9 were cultured and harvested as previously described (14). Under general anesthesia, a total of $4 \times 10^{7}$ cells were injected through a 27 -gauge needle at 40 different sites $\left(1 \times 10^{6}\right.$ cells $/ 10 \mu$ per site $)$ of skeletal muscle of both hind limbs in nude mice. All the experimental procedures were in accordance with institutional guidelines at the University of Southern California School of Medicine. Anesthetic agents included $20 \mathrm{mg} / \mathrm{kg}$ of ketamine hydrochloride and $3 \mathrm{mg} / \mathrm{kg}$ of xylazine hydrochloride (Sigma Chemical Co.).

Hematocrit measurement. Hematocrit was measured by the microhematocrit method (22). Each week under general anesthesia, $150 \mu \mathrm{l}$ of blood was collected by a retroorbital approach into two heparinized capillary tubes. On several occasions, we also measured the hematocrit using a Coulter Counter which showed results parallel to those obtained by the microhematocrit method (not shown). After hematocrit measurement, serum was recovered from the capillary tubes and stored at $-20^{\circ} \mathrm{C}$ for the measurement of EPO concentration and BUN.

Creation of renal failure model using nude mice. A renal failure model was created by a two-step nephrectomy (23) using 7-8 wk-old male nude mice. Under general anesthesia using sterile techniques, the right kidney was exposed through a flank incision and decapsulated, and the upper and lower poles (two thirds of the right kidney) were resected. The remnant right kidney was allowed to recover from swelling for a week, and then the total left kidney was resected. The animals were fed standard chow containing $24.0 \%$ protein and $1.0 \%$ phosphorus, and water ad libitum. Renal failure was confirmed by the development of both anemia and uremia. For uremia, blood urea nitrogen (BUN) was determined weekly with a BUN kit using $4 \mu \mathrm{l}$ of serum.

Measurement of serum EPO concentration. Serum concentrations of human EPO were determined by an enzyme linked immunosorbent assay (ELISA) system using a mouse monoclonal antibody according to the manufacturer's protocol. This method has a linear range between 2.5 and $200 \mathrm{mU} / \mathrm{ml}$ of human EPO with a detection threshold of 0.25 $\mathrm{mU} / \mathrm{ml}$.

$\beta$-galactosidase assays. After euthanasia, skeletal muscle tissue was excised and frozen immediately on dry ice. The excised muscles were then sectioned with a freezing microtome. The sections were attached to microscope slides, fixed in $0.25 \%$ glutaraldehyde for $10 \mathrm{~min}$, washed in PBS for $10 \mathrm{~min}$, and stained in PBS containing $1 \mathrm{mg} / \mathrm{ml}$ of X-gal, $5 \mathrm{mM}$ potassium ferricyanide, $5 \mathrm{mM}$ potassium ferrocyanide, and $2 \mathrm{mM}$ $\mathrm{MgCl}_{2}$. Sections were incubated at $37^{\circ} \mathrm{C}$ degree overnight, rinsed in PBS, mounted, studied under a microscope, and photographed.

Statistical analysis. Statistical significance was assessed by Student's $t$ test. $P<0.05$ was taken as significant. Data were expressed as means $\pm \mathrm{SD}$.

\section{Results}

Creation of renal failure model in mice. The major current clinical indication for recombinant human EPO protein is anemia in end-stage renal failure (24). We tested whether a myoblast gene transfer approach could be effective for the treatment of anemia in renal failure. We first attempted to create renal failure models that developed severe anemia allowing us to test the effect of C2-EPO9 transplantation. A two-step nephrectomy was performed in 27 male nude mice. Two thirds of the right kidney was resected first and a week later, the left kidney was totally resected. Two mice died shortly after the first nephrectomy, and eight after the second, presumably due to acute renal failure and/or bleeding. This mortality rate is comparable with a previous report (25). 17 mice that survived the acute phases of the two-step surgery were further followed weekly for the development of anemia and uremia, an indication for a successful nephrectomy. Hematocrit and BUN changes in these surviving mice are shown in Fig. 1. A week after the second nephrectomy, all the mice developed significant anemia (Fig. 1, $A$ and $B$ ). As shown in Fig. $1 A$, anemia improved somewhat for the following week in five mice, possibly due to EPO production in response to hypoxia from residual renal tissue and liver (Fig. $1 \mathrm{~A}$ ). Because of this tendency of hematocrit normalization, these five mice were followed without transplantation (group I). These group I mice did not develop further anemia (Fig. $1 A)$. Although BUN increase was obvious after the second nephrectomy in the group I mice (Fig. $1 B$ ), it remained moderate and was not progressive. In group $I$, only one mouse died during the experimental period, consistent with milder anemia and uremia. In the other 12 mice (group II), anemia was more severe and persistent (Fig. $1 C$ ). The mean hematocrit decreased from a preoperative level of $45.2 \pm 2.7$ to $33.9 \pm 3.7(\%) 3 \mathrm{wk}$ after the second nephrectomy. Since the hematocrit decrease appears to be relatively stabilized by week 3 in group II mice, these mice appeared to be ideal for testing the effect of C2-EPO9 transplantation. We decided to use some group II mice to study the efficacy of the transplantation. Eight mice were transplanted with C2-EPO9 cells (Fig. 1 C, solid lines), and three mice were followed without transplantation as control (Fig. $1 \mathrm{C}$, dashed lines) (one mouse died just before transplantation presumably due to severe uremia). All of the transplanted mice of group II had a marked hematocrit increase 


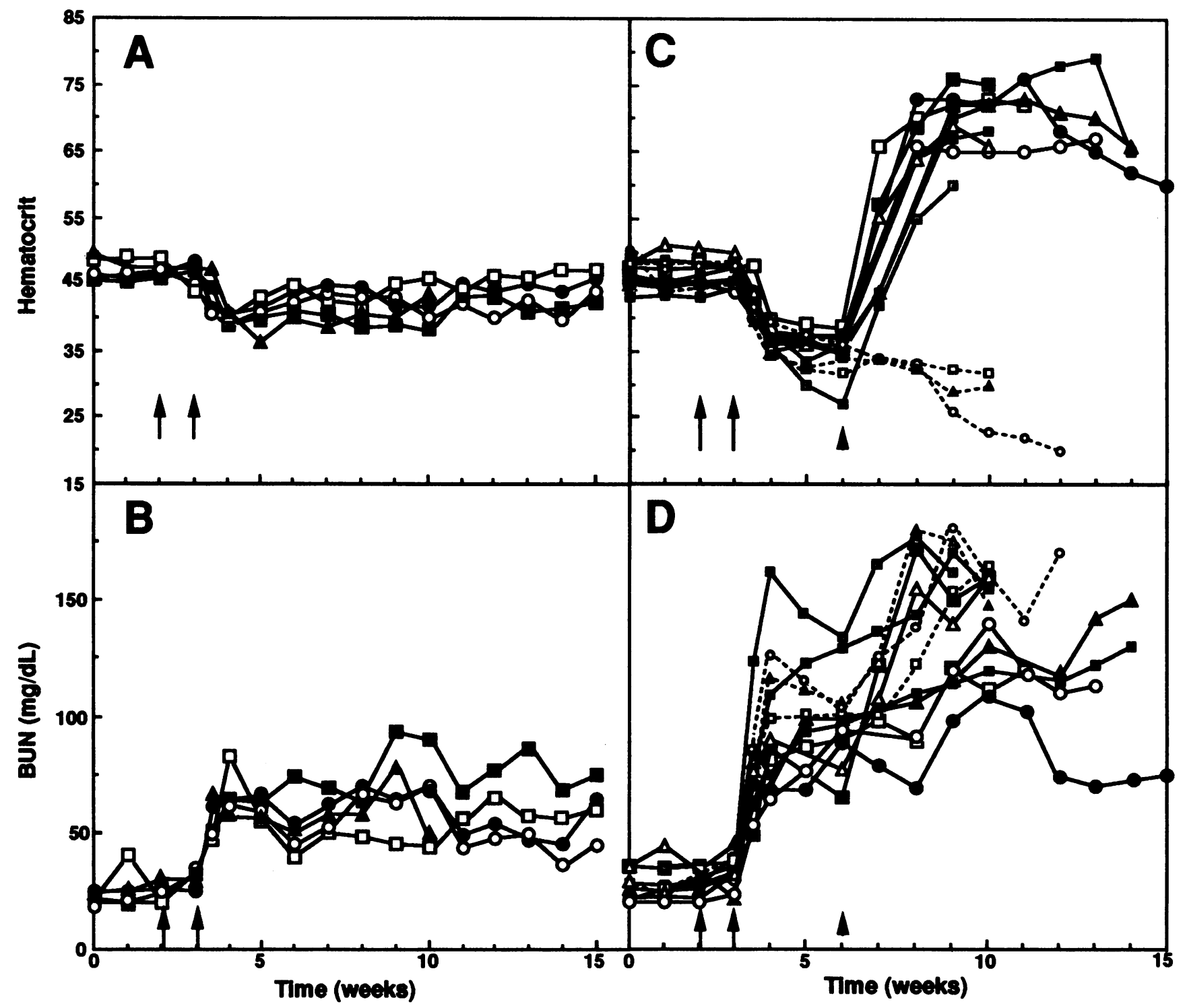

Figure 1. Persistent hematocrit increase by the transplantation of human EPO-producing myoblasts into nude mice with renal failure. ( $A$ and $B$ ) Group I mice with only transient anemia $(A)$ and a mild BUN increase $(B) .(C$ and $D)$ Group II mice with persistent anemia and a progressive BUN increase. Eight mice from group II were transplanted with $4 \times 10^{7}$ cells from C2-EP09 ( $C$ and $D$, solid lines), and three mice were followed without transplantation as a control ( $C$ and $D$, dashed lines). Each symbol represents the same individual mouse between $A$ and $B$, and between $C$ and $D$. In group I, all but one animal were alive at week 15 . In group II, only one animal $(\bullet)$ was alive at week 15 , and for the other animals the end of a line indicates the time of death. Arrows indicate the time of nephrectomy, and the arrow head indicates the time of cell transplantation.

(Fig. $1 C$ ), despite the presence of severe uremia as indicated by the progressively increasing BUN levels (Fig. $1 \mathrm{D}$ ). A mean hematocrit of $68.6 \pm 4.2 \%$ was achieved 2 wk after the transplantation, and this hematocrit increase persisted thereafter. Those without transplantation showed persistent or even deteriorating anemia (Fig. $1 \mathrm{C}$, dashed lines). BUN increase was much more striking $(95.4 \pm 16.5 \mathrm{mg} / \mathrm{dl})$ in group II (Fig. $1 D$ ) than in group I $(52.6 \pm 13.2 \mathrm{mg} / \mathrm{dl}$ three weeks after the second nephrectomy) (Fig. $1 B$ ). All of the group II mice, except one, died between 6 and $11 \mathrm{wk}(8.2 \pm 1.8 \mathrm{wk})$ after the second nephrectomy presumably due to severe uremia. The observed survival rate is consistent with previous observations (26). The one long term survivor in group II also had the lowest levels of BUN in that group (Figs. 1, C and D, closed circles). These data clearly demonstrate the feasibility and potential efficacy of a myoblast gene transfer system even in the face of severe renal failure in mice.

Serum EPO level. To examine the secretion of EPO protein from the transplanted cells, we measured serum human EPO concentration using an ELISA. We previously determined that this method did not detect a significant level of mouse EPO $(<2.5 \mathrm{mU} / \mathrm{ml})$ in sera of nude mice phlebotomized $(150 \mu \mathrm{l})$ weekly over 3 mo (unpublished observation). This observation was confirmed in the non-transplanted renal failure mice in group II (not shown). Thus, serum EPO measured by this method represents just the human EPO produced by the transplanted muscle cells and not endogenous EPO levels. A week after transplantation with C2-EPO9 cells, the serum EPO level 


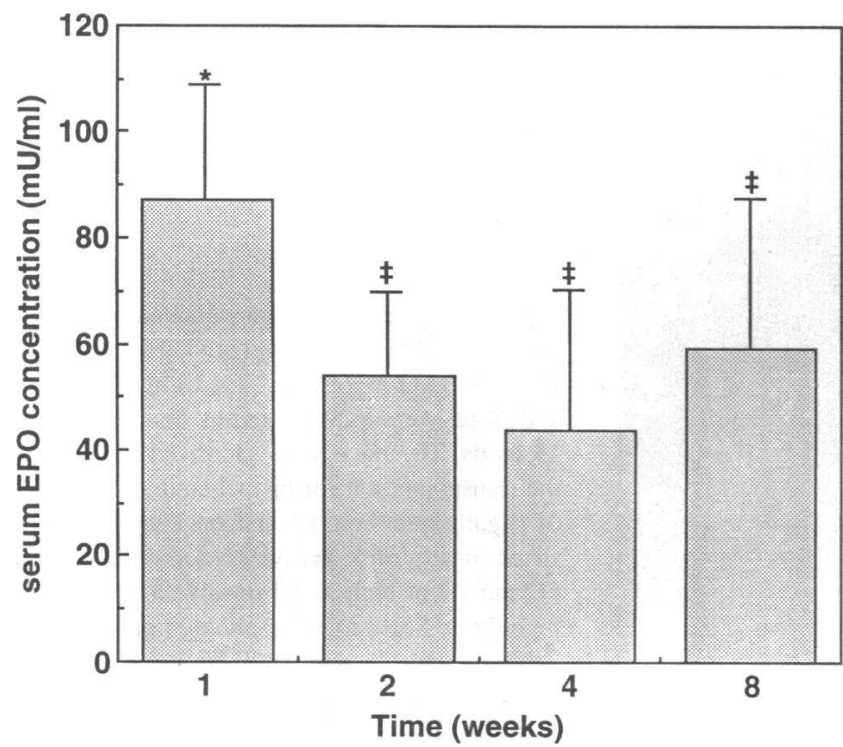

Figure 2. Persistent secretion of human EPO by transplantation of human EPO-producing myoblasts in nude mice with renal failure. Human EPO concentrations of the sera from the eight severely uremic mice that were transplanted with $\mathrm{C} 2$-EPO9 cells (Fig. $1 \mathrm{C}$, solid lines) were determined by ELISA. Sera from control mice (Fig. $1 C$, dashed lines) had $<2.5 \mathrm{mU} / \mathrm{ml}$ of EPO (not shown). * Significantly different from ${ }^{\ddagger}$. There was no significant difference among EPO levels measured at weeks 2,4 , and 8 .

was $87.3 \pm 22.1 \mathrm{mU} / \mathrm{ml}$ in group II uremic mice (Fig. 2). It declined to $53.8 \pm 18.7 \mathrm{mU} / \mathrm{m}$ at week 2 , and a similar concentration was maintained thereafter until week 8 . Thus, the transplanted C2-EPO9 cells persistently produced human EPO at a steady rate for at least 2 mo after transplantation into mice with severe renal failure.

The fate of transplanted EPO-secreting myoblasts in renal failure model. To analyze the fate of transplanted myoblasts, C2-EPO9 cells were transduced with BAG retrovirus (27) bearing $\beta$-galactosidase and neomycin resistence genes. Since the C2-EPO9 clone had already been maintained in the presence of G418, BAG-transduced clones were selected by positive Xgal staining. Cells from one X-gal positive clone (clone 9BAG) were expanded and transplanted into nude mice with renal failure according to the same protocol used for C2-EPO transplantation. These mice also showed a marked hematocrit increase from pre-transplantation level of $36.2 \pm 4.6 \%$ to $60.8 \pm 5.6 \% 4 \mathrm{wk}$ after the transplantation. Six weeks later, $X$ gal positive myofibers were detected in the entire area of transplantation. At some sites, most of the myofibers were X-gal positive (Fig. 3, $A$ and $B$ ), while at other sites, both X-gal positive and negative myofibers coexisted (Fig. 3, $C$ and $D$ ). However, we have been unable to detect $\mathrm{X}$-gal positive myoblasts. These results demonstrated that the transplanted EPOsecreting myoblasts differentiated by fusing with preexisting host myofibers or themselves and that the transgenes were actively expressed from the transplanted cells for the duration of the experimental protocol.

\section{Discussion}

Human EPO protein has a $79 \%$ amino acid homology with mouse EPO, and its administration induces marked erythropoie- sis in mice as well as other species of animals including rat and $\operatorname{dog}(28,29)$. To avoid immunological consequences engendered by human EPO produced in a different species, we used nude mice and attempted to determine the feasibility of a myoblast gene transfer approach in the treatment of renal failure. This gene therapy approach successfully met the prime requirements of (1) sufficient and (2) sustained secretion of (3) functional EPO transgene products, resulting in (4) a correction of anemia associated with renal failure (therapeutic systemic response), and thus demonstrated the potential therapeutic value of the approach.

We previously found that the transplantation of C2-EPO9 cells sustained a hematocrit increase for at least 3 mo in normal nude mice (14). Following this successful result, we attempted to correct anemia associated with renal failure, a major current indication for recombinant EPO therapy $(15,24)$. A number of clinical features of the uremic syndrome might be expected to adversely effect the outcome of a myoblast gene transfer approach for systemic EPO delivery. Wound repair processes after myoblast transplantation, for instance, could be much less efficient in uremic animals compared with normal animals due to poor nutrition, hemorrhagic diathesis, and infection (30). Myoblast gene transfer might be further hampered by uremic myopathy as well as polymyositis syndromes observed in chronic renal failure (30). It is unknown how other abnormalities in the uremic syndrome including electrolyte disorders, metabolic acidosis (i.e., glucose intolerance), gastrointestinal disorders, neurologic abnormalities, and metabolic disorders, might affect the outcome of myoblast transplantation. Furthermore, the erythroid response to EPO is significantly reduced, and red blood cell survival is shortened in uremia (30).

To our surprise, however, C2-EPO9 transplantation could, even in the face of severe uremia, deliver more than a sufficient amount of human EPO to correct anemia in nude mice with renal failure. The transplantation of $4 \times 10^{7}$ cells from $\mathrm{C} 2$ EPO9 increased hematocrit by $35 \%$ in renal failure mice (Fig. $1 C$ ), which is comparable with $27 \%$, the degree of hematocrit increase observed in non-uremic mice (14). Although the therapeutic effects lasted for at least $2 \mathrm{mo}$, longer periods of analysis were limited by animal death probably due to severe renal failure. However, with treatment of renal failure, it is likely that the hematocrit increase would persist for more than $2 \mathrm{mo}$, as was the case with non-uremic mice (14). The observation that the serum EPO concentration was still high at $2 \mathrm{mo}$, together with the fact that the half-life of red blood cells in mice is 20-45 d (31), also supports the likelihood that the increased hematocrit would have been sustained longer than $2 \mathrm{mo}$, if the uremia had been corrected by dialysis. The sustained high serum human EPO concentration due to $\mathrm{C} 2-\mathrm{EPO} 9$ transplantation confirmed that the observed hematocrit increase was due to human EPO derived from the transplanted cells rather than endogenous mouse EPO. The persistent presence of $\mathrm{X}$-gal positive myofibers after clone 9-BAG transplantation further supports the notion that the transplanted myoblasts differentiate into myofibers and become a stable source of EPO production in the face of renal failure.

We have frequently observed tumor formation in the transplanted nude mice after 2-3 mo. However, these tumor cells are not likely to contribute to the observed hematocrit increase, since the cultured tumor cells recovered from the tumor of one mouse did not secrete any detectable amount of human EPO by ELISA (not shown). Furthermore, the serum EPO concen- 


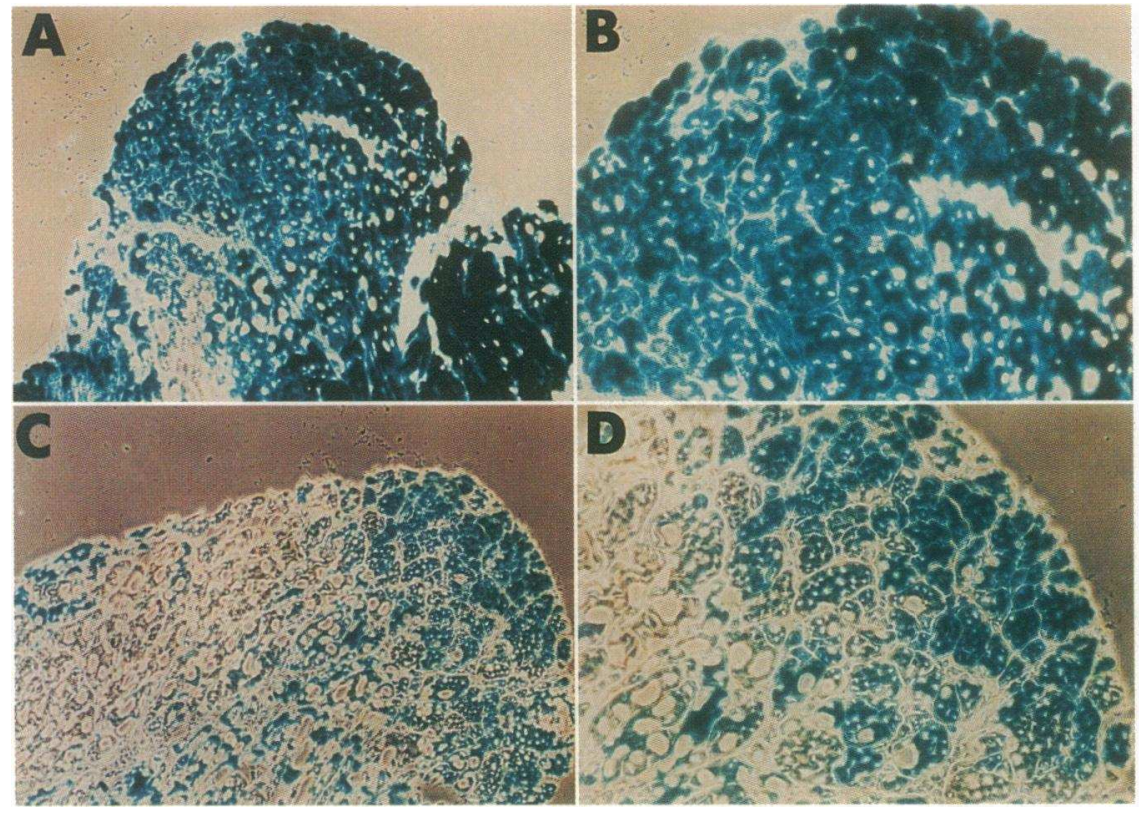

Figure 3. Persistence of transplanted EPO-producing myoblasts as differentiated myofibers. Clone 9-BAG myoblasts expressing both EPO and $\beta$-gal were transplanted as described in Methods. The mice were sacrificed $6 \mathrm{wk}$ after the transplantation for histochemical detection of $\beta$-gal expression. ( $A$ and $B$ ) The site consisted mostly of $\mathrm{X}$-gal positive myofibers, and $(C$ and $D$ ) of both $\mathrm{X}$-gal positive and negative myofibers. Sections were photographed at $\times 100(A$ and $C)$, and $\times 400(B$ and $D)$ magnification. $B$ and $D$ are magnifications of $A$ and $C$, respectively. The photographs shown are representatives of four nude mice with renal failure. tration remains relatively constant despite growing tumor size. Thus, it seems that myofibers derived from C2-EPO9 cells are responsible for the persistent hematocrit increase.

End-stage renal failure patients as well as patients with hypoproliferative anemia secondary to 3 '-azido-3'-deoxythymidine (AZT) administration are currently treated with 100-150 $\mathrm{U}$ of recombinant EPO per $\mathrm{kg}$ of body weight per week to maintain a target hematocrit level between 30 and $33(14,15)$, which is equal to $857-1286 \mathrm{U} /$ day for a $60-\mathrm{kg}$ patient. Since C2-EPO9 secretes $32.8 \mathrm{U}$ of EPO/106 cells per day, $3.9 \times 10^{7}$ cells would, in theory, be sufficient to provide $1286 \mathrm{U} /$ day. The delivery of this number of muscle cells appears to be feasible, since in a phase I clinical trial of myoblast transfer in Duchenne muscular dystrophy patients, as many as $10^{8}$ myoblasts could be prepared from small muscle biopsy (0.5-1.0 grams) of first degree relatives and transplanted into patients (32). However, a more accurate calculation would be needed for human application of the technique, based on the information regarding the nature of erythroid response to exogenously provided human EPO as well as efficiency of myoblast transplantation.

The present myoblast gene transfer system would be optimized for possible clinical applications. To this end, we have begun experiments to explore two different approaches: $(a)$ the use of primary myoblasts and $(b)$ the use of an implantable immunoisolation device. Although primary myoblasts transfected with EPO cDNA can secrete EPO and increase hematocrit in mice (33), this approach would require customized preparation of cells for an individual patient to avoid immunorejection. In this regard, a stocked cell line with an immunoisolation device might be a more practical approach for a large population of patients. Within such a device transformed myoblasts appear to retain an ability to differentiate (34) and are likely to become a stable source of recombinant protein production.

Although mice appear to tolerate the unusually high hematocrit for several months (35), overproduction of EPO could have potentially deleterious consequences including polycythemia $(36,37)$. Although we and others have found that recombinant gene production can be controlled to some degree by the number of cells transplanted (unpublished observation) (10), regulated transgene expression could also be achieved, for example, by use of inducible promoters to drive genes of interest $(38,39)$.

The major point of the present study was the demonstration (a) that myoblast gene transfer technology could correct a disease condition (correction of anemia) as a systemic response to EPO transgene expression, and $(b)$ that myoblast gene transfer is feasible for delivery of genes of interest (not restricted to EPO) in the setting of severe uremia, a disease condition previously untested for this approach. The result opens the possibility of delivering EPO, as well as other genes, to treat disease conditions in renal failure patients by myoblast gene transfer. This system may eventually offer an alternate, possibly more efficient gene therapy approach for the treatment of anemia associated with renal failure as well as other EPO-responsive anemias which must otherwise be treated with life-long repeated administrations of recombinant EPO protein.

\section{Acknowledgments}

We thank J. Igaki and C. Holder (Amgen, Thousand Oaks, CA) for in vitro bioassays, T. Saluna and S. Buranen (University of Southern California, CA) for their expert technical assistance, M. Ito and V. Sartorelli for useful discussions.

This work was supported in part by a grant to L. Kedes from the National Cancer Institute.

\section{References}

1. Evans, R. W. 1991. Recombinant human erythropoietin and the quality of life of end-stage renal disease patients: a comparative analysis. Am. J. Kidney Dis. 18:62-70.

2. Nabel, G. J., E. G. Nabel, Z. Y. Yang, B. A. Fox, G. E. Plautz, X. Gao, L. Huang, S. Shu, D. Gordon, and A. E. Chang. 1993. Direct gene transfer with DNA-liposome complexes in melanoma: expression, biologic activity, and lack of toxicity in humans. Proc. Natl. Acad. Sci. USA. 90:11307-11311.

3. Oldfield, E. H., Z. Ram, K. W. Culver, R. M. Blaese, H. L. DeVroom, and W. F. Anderson. 1993. Gene therapy for the treatment of brain tumors using intra- 
tumoral transduction with the thymidine kinase gene and intravenous ganciclovir. Human Gene Therapy. 4:39-69.

4. Kay, M. A., S. Rothenberg, C. N. Landen, D. A. Bellinger, F. Leland, C Toman, M. Finegold, A. R. Thompson, M. S. Read, K. M. Brinkhous, and S. L. C. Woo. 1993. In vivo gene therapy of hemophilia B: Sustained partial correction in factor IX-deficient dogs. Science (Wash. DC). 262:117-119.

5. Smith, T. A. G., M. G. Mehaffey, D. B. Kayda, J. M. Saunders, S. Yei, B. C. Trapnell, A. McClelland, and M. Kaleko. 1993. Adenovirus mediated expression of therapeutic plasma levels of human factor IX in mice. Nature Genetics. 5:397-402.

6. Webster, C., G. K. Pavlath, D. R. Parks, F. S. Walsh, and H. M. Blau. 1988. Isolation of human myoblasts with the fluorescence-activated cell sorter. Exp. Cell Res. 174:252-265.

7. Gunning, P., E. Hardeman, R. Wade, P. Ponte, W. Bains, H. Blau, and L. Kedes. 1987. Differential patterns of transcript accumulation during human myogenesis. Mol. Cell. Biol. 7:4100-4114.

8. Barr, E., and J. M. Leiden. 1991. Systemic delivery of recombinant proteins by genetically modified myoblasts. Science (Wash. DC). 254:1507-1509.

9. Dhawan, J., L. C. Pan, G. K. Pavlath, M. A. Travis, A. M. Lanctot, and H. M. Blau. 1991. Systemic delivery of human growth hormone by injection of genetically engineered myoblasts. Science (Wash. DC). 254:1509-1512.

10. Dai, Y., M. Roman, R. K. Naviaux, and I. M. Verma. 1992. Gene therapy via primary myoblasts: long-term expression of factor IX protein following transplantation in vivo. Proc. Natl. Acad. Sci. USA. 89:10892-10895.

11. Hughes, S., and H. Blau. 1990 . Migration of myoblasts across basal lamina during skeletal muscle development. Nature (Lond.). 345:350-353.

12. Karpati, G., Y. Pouliot, G. E. Zubrzycka, S. Carpenter, P. N. Ray, R. G. Worton, and P. Holland. 1989. Dystrophin is expressed in mdx skeletal muscle fibers after normal myoblast implantation. Am. J. Pathol. 135:27-32.

13. Law, P. K., T. G. Goodwin, and M. G. Wang. 1988. Normal myoblast injections provide genetic treatment for murine dystrophy. Muscle Nerve. 11:525533.

14. Hamamori, Y., B. Samal, J. Tian, and L. Kedes. 1994. Persistent erythropoiesis by myoblast transfer of erythropietin cDNA. Human Gene Therapy. 5:1349-1356.

15. Faulds, D., and E. M. Sorkin. 1989. Epoetin (recombinant human erythropoietin) a review of its pharmacodynamic and pharmacokinetic properties and therapeutic potential in anemia and the stimulation of erythropoiesis. Drugs. 38:863-899.

16. Semenza, G. L., R. C. Dureza, M. D. Traystman, J. D. Gearhart, and S. E. Antonarakis. 1990. Human erythropoietin gene expression in transgenic mice: Multiple transcription initiation sites and cis-acting regulatory elements. $\mathrm{Mol}$. Cell. Biol. 10:930-938.

17. Lin, F.-K., S. Suggs, C.-H. Lin, J. K. Browne, R. Smalling, J. C. Egrie K. K. Chen, G. M. Fox, F. Martin, Z. Stabinsky, S. M. Badrawi, P.-H. Lai, and E. Goldwasser. 1985. Cloning and expression of the human erythropoietin gene. Proc. Natl. Acad. Sci. USA. 82:7580-7584.

18. Jacobs, K., C. Shoemaker, R. Rudersdorf, S. D. Neill, R. J. Kaufman, A Mufson, J. Seehra, S. S. Jones, R. Hewick, E. F. Fritsch, M. Kawakita, T. Shimizu, and T. Miyake. 1985. Isolation and characterization of genomic and cDNA clones of human erythropoietin. Nature (Lond.). 313:806-810.

19. Hennighausen, L. and B. Fleckenstein. 1986. Nuclear factor 1 interacts with five DNA elements in the promoter region of the human cytomegalovirus major immediate early gene. EMBO (Eur. Mol. Biol. Organ.) J. 5:1367-1371.

20. Lubon, H., P. Ghazal, L. Hennighausen, C. Reynolds-Kohler, C. Lockshin, and J. Nelson. 1989. Cell-specific activity of the modulator region in the human cytomegalovirus major immediate-early gene. Mol. Cell. Biol. 9:1342-1345.
21. Southern, P. J., and P. Berg. 1982. Transformation of mammalian cells to antibiotic resistance with a bacterial gene under control of the SV40 early region promoter. J. Mol. Appl. Gen. 1:327-341.

22. Koepke, J. A. 1991. Practical Laboratory Hematology. Churchill Livingstone, New York. 112 pp.

23. Chanutin, A. and J. E. B. Ferris. 1932. Experimental renal insufficiency produced by partial nephrectomy. Arch. Intern. Med. 49:767-787.

24. Powe, N. R., R. I. Griffiths, G. de Lissovoy, G. F. Anderson, A. J. Watson, J. W. Greer, R. J. Herbert, P. W. Eggers, R. A. Milam, and P. K. Whelton. 1992. Access to recombinant erythropoietin by medicare-entitled dialysis patients in the first year after FDA approval. JAMA. 268:1434-1440.

25. Gibb, I. A. and D. N. H. Hamilton. 1985. An experimental model of chronic renal failure in mice. Clin. Immunol. Immunopathol. 35:276-284.

26. Kumano, K., K. Kogure, T. Tanaka, and T. Sakai. 1986. A new method of inducing experimental chronic renal failure by cryosurgery. Kidney Int. 30:433436.

27. Price, J., D. Turner, and C. Cepko. 1987. Lineage analysis in the vertebrate nervous system by retrovirus-mediated gene transfer. Proc. Natl. Acad. Sci. USA. 84:156-160.

28. Egrie, J. C., T. W. Strickland, J. Lane, K. Aoki, A. M. Cohen, R. Smalling, G. Trail, F. K. Lin, J. K. Browne, and D. K. Hines. 1986. Characterization and biological effects of recombinant human erythropoietin. Immunobiol. 172:213224.

29. Browne, J. K., A. M. Cohen, J. C. Egrie, P. H. Lai, F.-K. Lin, T. Strickland, E. Watson, and N. Stebbing. 1986. Erythropoietin: Gene cloning, protein structure, and biological Properties. Cold Spring Harbor Symposia on Quantitative Biology. L1:693-702.

30. Wyngaaden, J. B. L. H. Smith, and J. C. Bennett. Cecil Textbook of Medicine. 19th edition. 1992. W. B. Saunders, Philadelphia, PA. 533-541.

31. Bannerman, R. M. 1983. The mouse in biomedical research. Hematology. Vol. III. H. L. Foster, J. D. Small, and J. G. Fox, editors. Academic press; New York. 294-308.

32. Gussoni, E., G. K. Pavlath, A. M. Lanctot, K. R. Sharma, R. G. Miller, L. Steinman, and H. M. Blau. 1992. Normal dystrophin transcripts detected in Duchenne muscular dystrophy patients after myoblast transplantation. Nature (Lond.). 356:435-438.

33. Barr, E., S. Tripathy, and J. M. Leiden. 1994. Genetically modified myoblasts for the treatment of erythropoietin-responsive anemias. J. Cell. Biochem. Suppl. 18A:DZ012 (Abstr.).

34. Liu, H.-W., F. A. Ofosu, and P. L. Chang. 1993. Expression of Human Factor IX by microencapsulated recombinant fibroblasts. Human Gene Therapy. 4:291-301.

35. Semenza, G. L., M. D. Traystman, J. D. Gearhart, and S. E. Antonarakis. 1989. Polycythemia in transgenic mice expressing the human erythropoietin gene Proc. Natl. Acad. Sci. USA. 86:2301-2305.

36. Garcia, D. L., S. Anderson, H. G. Rennke, and B. M. Brenner. 1988. Anemia lessens and its prevention with recombinant human erythropoietin worsens glomerular injury and hypertension in rats with reduced renal mass. Proc. Natl. Acad. Sci. USA. 85:6142-6146.

37. Villeval, J.-L., D. Metcalf, and G. R. Johnson. 1992. Fatal polycythemia induced in mice by dysregulated erythropoietin production by hematopoietic cells Leukemia. 6:107-115.

38. Lee, F., R. Mulligan, P. Berg, and G. Ringold. 1981. Glucocorticoids regulate expression of dihydrofolate reductase cDNA in mouse mammary tumor virus chimeric plasmids. Nature (Lond.). 294:228-232.

39. Gossen, M., and H. Bujard. 1992. Tight control of gene expression in mammalian cells by tetracycline-responsive promoters. Proc. Natl. Acad. Sci. USA. 89:5547-5551. 